\title{
Trophic relationships in a deep Mediterranean cold-water coral bank (Santa Maria di Leuca, Ionian Sea)
}

\author{
A. Carlier ${ }^{1, *}$, E. Le Guilloux ${ }^{2}$, K. Olu ${ }^{2}$, J. Sarrazin ${ }^{2}$, F. Mastrototaro ${ }^{3}$, M. Taviani ${ }^{4}$, \\ J. Clavier ${ }^{1}$ \\ ${ }^{1}$ LEMAR, UMR 6539 (CNRS-UBO-IRD), Institut Universitaire Européen de la Mer, Technopôle Brest Iroise, \\ Place Nicolas Copernic, 29280 Plouzané, France \\ ${ }^{2}$ DEEP/LEP, Ifremer, Centre de Brest, BP 70, 29280 Plouzané, France \\ ${ }^{3}$ ULR CoNISMa - Dipartimento di Biologia Animale ed Ambientale, Università degli Studi di Bari, Via Orabona, \\ 4 - 70125 Bari, Italy \\ ${ }^{4}$ ISMAR-CNR, via Gobetti 101, 40129 Bologna, Italy
}

\begin{abstract}
Cold-water corals (CWC) are frequently reported from deep sites with locally accelerated currents that enhance seabed food particle supply. Moreover, zooplankton likely account for ecologically important prey items, but their contribution to CWC diet remains unquantified. We investigated the benthic food web structure of the recently discovered Santa Maria di Leuca (SML) CWC province (300 to $1100 \mathrm{~m}$ depth) located in the oligotrophic northern Ionian Sea. We analyzed stable isotopes $\left(\delta^{13} \mathrm{C}\right.$ and $\delta^{15} \mathrm{~N}$ ) of the main consumers (including ubiquitous CWC species) exhibiting different feeding strategies, zooplankton, suspended particulate organic matter (POM) and sedimented organic matter (SOM). Zooplankton and POM were collected $3 \mathrm{~m}$ above the coral colonies in order to assess their relative contributions to CWC diet. The $\delta^{15} \mathrm{~N}$ of the scleractinians Desmophyllum dianthus, Madrepora oculata and Lophelia pertusa (8 to 9\%) and the gorgonian Paramuricea cf. macrospina (9 to $10 \%$ ) were consistent with a diet mainly composed of zooplankton (6 to $7 \%$ ). The antipatharian Leiopathes glaberrima was more ${ }^{15} \mathrm{~N}$-depleted ( 7 to $8 \%$ ) than other cnidarians, suggesting a lower contribution of zooplankton to its diet. Our $\delta^{13} \mathrm{C}$ data clearly indicate that the benthic food web of SML is exclusively fuelled by carbon of phytoplanktonic origin. Nevertheless, consumers feeding at the water-sediment interface were more ${ }^{13} \mathrm{C}$-enriched than consumers feeding above the bottom (i.e. living corals and their epifauna). This pattern suggests that carbon is assimilated via 2 trophic pathways: relatively fresh phytoplanktonic production for ${ }^{13} \mathrm{C}$-depleted consumers and more decayed organic matter for ${ }^{13} \mathrm{C}$-enriched consumers. When the $\delta^{13} \mathrm{C}$ values of consumers were corrected for the influence of lipids (which are significantly ${ }^{13} \mathrm{C}$-depleted relative to other tissue components), our conclusions remained unchanged, except in the case of L. glaberrima which could assimilate a mixture of zooplankton and resuspended decayed organic matter.
\end{abstract}

KEY WORDS: Cold-water corals $\cdot$ Benthic community $\cdot$ Mediterranean Sea $\cdot$ Food web $\cdot$ Stable isotopes $\cdot$ Zooplankton $\cdot$ Particulate organic matter

\section{INTRODUCTION}

Like their shallow-water tropical counterparts, coldwater corals (CWC; also called deep-water corals) are organisms of major ecological importance in deep ocean environments (Roberts et al. 2006). In spite of a still low number of quantitative studies, CWC reefs may have a comparable biodiversity to that found on tropical coral reefs and have therefore been considered as benthic biodiversity hotspots (Henry \& Roberts 
2007, Mastrototaro et al. 2010). They also act as a potential refuge, nursery and feeding ground for many deep-sea species, including commercial fishes (Husebø et al. 2002, Krieger \& Wing 2002, Costello et al. 2005, Ross \& Quattrini 2007, D'Onghia et al. 2010). CWC are, however, under increasing anthropogenic threats, e.g. directly from deep trawling (Fosså et al. 2002), gas and oil exploitation, or indirectly from ocean acidification (Turley et al. 2007). In addition, they are vulnerable to the warming of the deep Mediterranean Sea (Bethoux et al. 1990) because they live at temperatures $\left(\sim 14^{\circ} \mathrm{C}\right)$ close to their tolerance limits (Freiwald et al. 2004). Since their ecology is still poorly understood, there is an urgent need to improve knowledge on the structure and function of these sensitive benthic ecosystems.

Among many other life history traits, the feeding mode of CWC is still unclear. Since all CWC (e.g. Scleractinia, Antipatharia, Octocorallia) lack endosymbiotic zooxanthellae, they should exclusively depend on external inputs of organic matter (from dissolved organic matter to macrozooplankton) for their feeding, as evidenced for some shallow tropical scleractinians (Anthony \& Fabricius 2000, Houlbrèque \& FerrierPagès 2009). The distribution of CWC has been directly related to the presence of hard topographic highs and enhanced currents that are strong enough to prevent burial by deposition of fine sediment and provide rapid transport of fresh and labile food particles to the coral polyps (Thiem et al. 2006, Kiriakoulakis et al. 2007). Consequently, these benthic ecosystems are likely indirectly fuelled by surface primary production via sinking fluxes of particles (phytodetritus, fecal pellets) (Duineveld et al. 2004). However, direct observations have shown that CWC are also able to catch and ingest prey, such as zooplankton, up to $2 \mathrm{~cm}$ in length (Mortensen 2001, Freiwald 2002). The relative proportions of suspended particulate organic matter (POM) and zooplankton to the diet of CWC remain unknown.

Natural carbon and nitrogen stable isotope abundance $\left(\delta^{13} \mathrm{C}\right.$ and $\left.\delta^{15} \mathrm{~N}\right)$ in the tissue of a consumer is now widely used to assess its diet (Fry 2006). This technique provides dietary information integrated over a time corresponding to the turnover of the tissue (e.g. several weeks or months for muscle), and is particularly useful for less accessible areas such as deep-sea benthic ecosystems as only a small amount of material is required for stable isotope analysis (Iken et al. 2001, Becker et al. 2009).

So far, $\delta^{13} \mathrm{C}$ data obtained for CWC worldwide (typically between -22 and $-18 \%$ ), and in particular for the 2 cosmopolitan scleractinians Lophelia pertusa and Madrepora oculata, evidenced that these species depend (at least indirectly) on phytoplanktonic production for their food (Duineveld et al. 2004, Sherwood et al. 2008, Becker et al. 2009, Le Guilloux et al. 2009). These data also ruled out the hypothesis of a trophic link with seeping hydrocarbons, which are much more ${ }^{13} \mathrm{C}$-depleted than phytoplankton. Recent $\delta^{15} \mathrm{~N}$ data from the Rockall Bank (NE Atlantic) suggested that $L$. pertusa and M. oculata behave like filter feeders and mainly assimilate POM (Duineveld et al. 2007). On the basis of $\delta^{13} \mathrm{C}$ and $\delta^{15} \mathrm{~N}$ analyses, Duineveld et al. (2004) assumed that these species assimilate a mixture of POM and small zooplankton (copepods, amphipods) on the Galicia Bank (NW Spain). In this case, the analysed zooplankton was recovered with near-bottom sediment traps. Kiriakoulakis et al. (2005), using both lipid biomarkers and $\delta^{15} \mathrm{~N}$, argued that $L$. pertusa and M. oculata primarily feed on zooplankton. Recently, Sherwood et al. (2008) showed that 11 coral species of the NW Atlantic Canadian margin display a continuum of trophic niches from exclusive suspension feeding on phytodetritus to true carnivorous behavior. Up to now, data on the trophic ecology of CWC remain scarce, concern mostly the northern Atlantic Ocean and do not always refer to material collected in the close vicinity of the reefs (which is only possible by the use of submersibles). Previous studies suggest that feeding behaviour of these species may vary depending on geographic location as well as many important environmental factors (e.g. seasonality, surface primary production, hydrodynamics) (Duineveld et al. 2004, 2007, Kiriakoulakis et al. 2005, Sherwood et al. 2008).

In the Mediterranean Sea, although the existence of CWC has been known for more than a century (Pérès 1967, Zibrowius 1980, Taviani et al. 2005), these ecosystems have only been recently investigated in great detail, since 2000 on the Santa Maria di Leuca (SML) province (northern Ionian Sea, 300 to $1100 \mathrm{~m}$ depth) (Mastrototaro et al. 2002, 2010, Tursi et al. 2004) and lately in the Eastern Ionian Sea (Strait of Sicily, 400 to $600 \mathrm{~m}$ depth) (Schembri et al. 2007) and the northwestern Mediterranean Sea (Cap de Creus Canyon, 200 to $400 \mathrm{~m}$ depth) (Orejas et al. 2008). CWC of the SML were explored by submersible for the first time in 2006 and mapped from later dives in 2007. Although some Mediterranean CWC communities are well described (e.g. in the SML province; Tursi et al. 2004, Mastrototaro et al. 2010), there is still no published data on the trophic ecology of these systems. Thus, given the unique ecological context of the deep Mediterranean Sea (e.g. oligotrophy, high temperature and salinity) and the specific evolution history of its coral species, it is essential to better understand the trophic ecology of Mediterranean CWC and to compare this knowledge to that obtained for their Atlantic counterparts.

Within the framework of the European Hotspot Ecosystems Research on the Margins of European Seas (HERMES; 2005-2009) project, we investigated the 
deep CWC community of the SML coral province in 2007 using the French remotely operated vehicle (ROV) 'Victor 6000'. In the present study, we used $\delta^{13} \mathrm{C}$ and $\delta^{15} \mathrm{~N}$ analysis of in situ sampled fauna, particles and sediment to describe the structure of the benthic food web related to this CWC ecosystem. For this purpose, we focused on 18 dominant macro- and megafauna species of the SML CWC mounds. We also evaluated the trophic role of zooplankton in the diet of several co-occurring cnidarian species, including the ubiquitous scleractinian species Lophelia pertusa and Madrepora oculata.

\section{MATERIALS AND METHODS}

Study area. The investigated CWC communities are located along the Apulian margin, 15 miles off Cape of Santa Maria di Leuca (southern Italy, northern Ionian Sea) (Fig. 1). This coral province stretches over a broad area $\left(900 \mathrm{~km}^{2}\right.$, between 300 and $1100 \mathrm{~m}$ depth) and is formed by clustered and isolated mound-like features 50 to $300 \mathrm{~m}$ in length and up to $30 \mathrm{~m}$ high (Taviani et al. 2005, Corselli et al. 2006, Savini \& Corselli 2010). Living CWC in the SML thrive at $13.8^{\circ} \mathrm{C}$ (Taviani et al. 2005) and coral frameworks are mainly built by the colonial scleractinians Madrepora oculata and Lophelia pertusa (see Vertino et al. 2010 for pictures). The local hydrology is characterised by the presence of the Adriatic Deep Water, a core of less saline and oxygenated water flowing from the Adriatic to the Ionian Sea moving in geostrophic balance along the isobaths at 600 to $1000 \mathrm{~m}$ (Budillon et al. 2010). Strong unidirectional bottom currents in the SML are evidenced by seafloor features such as sediment drifts and seafloor erosion (Taviani et al. 2005, Savini \& Corselli 2010) and bioerosion patterns (Beuck et al. 2010). The investigated CWC mounds are mainly located at depths of 550 to $700 \mathrm{~m}$ on 2 neighbouring mounds: 'Reef $\mathrm{A}$ ' and 'Atlantis mound' (Fig. 1). In addition, 2 faunal samples were collected at $1100 \mathrm{~m}$ depth. Reef A was investigated for the first time in 2006 during the M70-1 (HERMES) cruise (Freiwald et al. 2009) and was later mapped in 2007 (E. Le Guilloux unpubl. data). Atlantis mound was previously investigated in 2005 during the APLABES cruise using a towed camera (MODUS module) and has also been referred to as the 'MS04 area' (Etiope et al. 2010, Savini \& Corselli 2010, Vertino et al. 2010). These investigations revealed dense coverage of live and dead-fossil coral framework ca. 0.5 to $1 \mathrm{~m}$ high on these 2 CWC mounds ( 30 m high and 200 to $300 \mathrm{~m}$ length), and showed that living frameworkbuilding corals are mainly distributed on the eastern flank facing the main bottom current, whereas the western flank is mud-dominated and hosts large antipatharian (Leiopathes glaberrima) colonies (Mas-

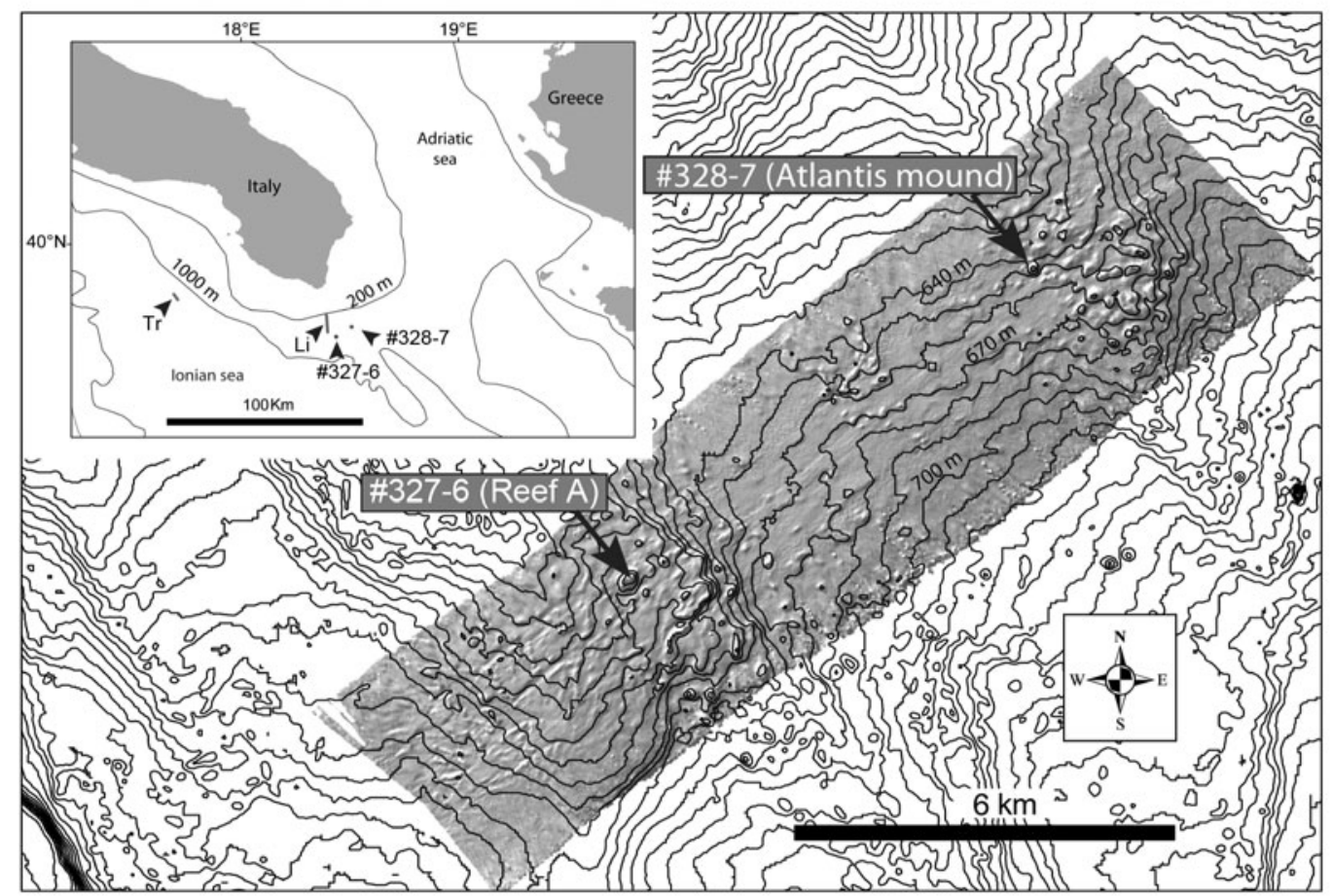

Fig. 1. Santa Maria di Leuca sampling sites. Tr: trawl (2006 GAVIS cruise); Li: long-line (2005 APLABES cruise); \#327-6 and \#328-7: ROV dives on Reef A and Atlantis mound, respectively (2007 MEDECO cruise). The shaded view of the bathymetrical data was obtained with the $24 \mathrm{kHz}$ multibeam echo-sounder of the RV 'Pourquoi pas?' during the MEDECO cruise (gridding parameter $20 \mathrm{~m}$ ) 
trototaro et al. 2009, Vertino et al. 2010). These observations suggest that hydrodynamics strongly influence the megafaunal distribution in these areas.

Sample collection. Sampling in the SML was achieved mainly during the MEDECO cruise (October 2007) onboard the RV 'Pourquoi Pas?' and to a lesser extent during: (1) the APLABES cruise (September 2005) at $520 \mathrm{~m}$ depth using long-lines (colonies of coral trapped in the threads of nylon); (2) the GAVIS cruise (September 2006) at 1100 m depth using trawling; and (3) the M70-1 cruise (October 2006) onboard the RV 'Meteor' (see Table 1 for details). A total of 45 samples of 18 species of mega- and macrofauna were collected. The ROV 'Victor 6000', equipped with manipulator arms, was deployed during the MEDECO cruise and carried out faunal sampling on Reef A (Dive no. 327-6) and Atlantis mound (Dive no. 328-7) (Table 1). We selected taxa that are dominant on SML mounds (Tursi et al. 2004, Mastrototaro et al. 2009) and also emblematic and ubiquitous on CWC reefs worldwide (Freiwald et al. 2004). In particular, we collected 4 key species of CWC ecosystems: the scleractinians Madrepora oculata, Lophelia pertusa and Desmophyllum dianthus and the polychaete Eunice norvegica. The selected set of 18 species display different feeding behaviors which encompass the overall benthic food web of the SML. Most of the investigated species are benthic and live in close association with the coral framework. Thus they were collected either in the living and erected part of CWC colonies (the spider crab Rochinia rissoana) or among its dead components at the bottom (the bivalve Asperarca nodulosa, the polychaete Serpula vermicularis and the sponges Poecillastra compressa and Pachastrella monilifera). A plankton net (mesh size $65 \mu \mathrm{m}$ ) was operated by the ROV during Dive no. 325-4 to collect living zooplankton (for $20 \mathrm{~min}$ ) $3 \mathrm{~m}$ above CWC colonies located $1 \mathrm{~km}$ apart from Reef A. Three species of zooplankton (Platyscelidae sp., Phrosinidae sp. and Euphausiidae sp.) $>250 \mu \mathrm{m}$ length were analysed since they represented a very large biomass fraction of the recovered material.

POM was sampled during the MEDECO cruise at 2 different sites by pumping and filtering $\sim 7.51$ seawater for $30 \mathrm{~min}$ (corresponding to a flow rate of $\sim 250 \mathrm{ml}$ $\mathrm{min}^{-1}$ ) $3 \mathrm{~m}$ above the bottom and close to dense colonies of Madrepora oculata. This was achieved using a new water multi-sampler (PEPITO) equipped with a peristaltic pump developed by IFREMER and mounted on the ROV. Each POM sample was recovered on 1 single pre-combusted $\left(500^{\circ} \mathrm{C}_{i} 4 \mathrm{~h}\right) 47 \mathrm{~mm}$ Whatman GF/F filter.

Sedimented organic matter (SOM) was sampled during the MEDECO cruise with blade corers (a corer with a closing mechanism, a rectangular $100 \times 50 \mathrm{~mm}$ section and $200 \mathrm{~mm}$ in height) and cylinder push corers deployed by the ROV in soft sediment areas between coral patches. These 2 sampling devices collect undisturbed sediment cores. Only the surficial layer (first $1 \mathrm{~cm}$ ) of each sample was used to analyse SOM.

Sample processing. Fresh specimens were dissected onboard and tissue samples were kept at $-20^{\circ} \mathrm{C}$ until analysis in the laboratory. Skeleton, shells and guts (when possible) were removed under binocular microscope using fine forceps. Depending on taxa, either the whole animal (polychaete, bivalve, zooplankton, sponge) or only muscles (fish, crab, sea urchin) were kept for analysis. Madrepora oculata samples collected in 2007 were fixed with formalin (4\%) for $24 \mathrm{~h}$ and then kept in ethanol $(70 \%)$. Eight other species (including 3 cnidarians) collected in October 2007 were conditioned both as fresh and formalin-fixed (formalin $4 \%$ for $24 \mathrm{~h}$ and ethanol $70 \%$ ) samples (Table 1). These samples were used to assess the effect of the formalin + ethanol treatment on the $\delta^{13} \mathrm{C}$ and $\delta^{15} \mathrm{~N}$ values by comparing formalin-fixed samples with paired fresh samples. Although it is known that frozen material gives optimal isotopic results, often deep-sea samples are recovered without being preserved ideally for stable isotope analysis. This data is therefore useful to the entire scientific community. The sample of Lophelia pertusa from the M70-1 cruise was preserved in glycerol $\left(\mathrm{C}_{3} \mathrm{H}_{8} \mathrm{O}_{3}\right)$ at $-80^{\circ} \mathrm{C}$, so we only considered the $\delta^{15} \mathrm{~N}$ values of this sample, assuming that $\delta^{15} \mathrm{~N}$ is not modified by glycerol.

For euphausiids, phrosinid amphipods and the bivalves Asperarca nodulosa and Delectopecten vitreus, several individuals $(5,15,10$ and 4 , respectively) were pooled per analysed sample. For the scleractinian corals Madrepora oculata, Lophelia pertusa and Desmophyllum dianthus, 5 polyps were pooled per analysed sample and replicates correspond to material collected from distinct colonies. All 50 samples (animal species, POM, SOM) were split into 2 parts: a subsample devoted to $\delta^{13} \mathrm{C}$ analysis was decarbonated by immersion in liquid $\mathrm{HCl}(10 \%)$ at room temperature, and a second subsample devoted to $\delta^{15} \mathrm{~N}$ analysis was kept untreated. The acidification lasted until the effervescence ceased (i.e. $<1$ min for soft animal tissues and POM filters and up to $5 \mathrm{~min}$ for dissected coral polyps). Sediment samples were freeze-dried and ground with a mortar and pestle. A subsample ( $500 \mathrm{mg}$ dry weight) was acidified with $10 \% \mathrm{HCl}$ drop by drop until the effervescence ceased and was dried at $50^{\circ} \mathrm{C}$ under a fume extractor to evaporate the acid. Sediment samples were not rinsed in order to prevent any loss of dissolved organic matter (Riera et al. 1996). They were instead mixed with distilled water and dried. This procedure was repeated twice. Sediment samples were then ground and kept frozen at $-20^{\circ} \mathrm{C}$ until analysis of SOM. 





Stable isotope analyses. Carbon and nitrogen stable isotope analyses were carried out using a SerCon 20/20 isotope ratio mass spectrometer coupled to an ANCA-GSL elemental analyser (SercCon). A 1:4 leucine:citric acid mixture was used as standard. The isotopic composition $\left(\delta^{13} \mathrm{C}\right.$ or $\left.\delta^{15} \mathrm{~N}\right)$ of each sample was expressed as the relative difference between isotopic ratios in the sample and in conventional standards (Vienna PeeDee Belemnite for carbon and atmospheric $\mathrm{N}_{2}$ for nitrogen):

$\delta^{13} \mathrm{C}$ or $\delta^{15} \mathrm{~N}(\%)=\left[\left(\mathrm{R}_{\text {sample }} / \mathrm{R}_{\text {standard }}\right)-1\right] \times 1000$

where $\mathrm{R}={ }^{13} \mathrm{C} /{ }^{12} \mathrm{C}$ or ${ }^{15} \mathrm{~N} /{ }^{14} \mathrm{~N}$.

The precision for $\delta^{13} \mathrm{C}$ and $\delta^{15} \mathrm{~N}$ was $\sim 0.1$ and $\sim 0.4 \%$, respectively (for samples with $\mathrm{N}$ content $>5 \%$ dry weight). Reproducibility (expressed as SD of the reference standards) was $<0.09$ and $<0.19 \%$ for $\delta^{13} \mathrm{C}$ and $\delta^{15} \mathrm{~N}$, respectively. C:N atomic ratios were calculated from the percentages of organic carbon and nitrogen obtained for each decarbonated sample.

Correction of $\boldsymbol{\delta}^{13} \mathbf{C}$ for lipid content. Since lipids are ${ }^{13} \mathrm{C}$-depleted relative to other compounds (e.g. proteins, hydrocarbonates) by around 6 to $8 \%$ (DeNiro \& Epstein 1977, McConnaughey \& McRoy 1979), different lipid contents can bias the interpretation of consumers' $\delta^{13} \mathrm{C}$ values. CWC in particular may exhibit variable lipid content (from 2 to $39 \%$; Hamoutene et al. 2008). Moreover, we investigated invertebrates belonging to very different taxa with potentially contrasting lipid contents. As a result, it was necessary to normalise our isotopic results for lipid. Because of insufficient quantities of recovered material, we were not able to extract lipid from our samples before their $\delta^{13} \mathrm{C}$ analysis. $\delta^{13} \mathrm{C}$ data were instead corrected for lipid a posteriori using the $\mathrm{C}: \mathrm{N}$ ratios as a proxy for lipid content and the following equation established by Post et al. (2007):

$$
\delta^{13} \mathrm{C}^{\prime}=\delta^{13} \mathrm{C}-3.32+(0.99 \times \mathrm{C}: \mathrm{N})
$$

where $\delta^{13} \mathrm{C}^{\prime}$ represents lipid-corrected $\delta^{13} \mathrm{C}$ values.

As the model proposed by Post et al. (2007) is based mainly on freshwater and estuarine species and has not yet been validated for deep-sea ecosystems, we also report the uncorrected $\delta^{13} \mathrm{C}$ values.

\section{RESULTS}

$\delta^{13} \mathrm{C}$ and $\delta^{15} \mathrm{~N}$ values of food web components that were collected at both Reef A and Atlantis mound exhibited small between-site differences $(<0.5 \%)$ (Table 2).

Both mean $\delta^{13} \mathrm{C}$ and $\delta^{15} \mathrm{~N}$ values were modified by preservative treatment (fixation with formalin and subsequent preservation in ethanol) by a range of $\pm 2.0 \%$ o (Fig. 2). $\delta^{15} \mathrm{~N}$ values of Eunice norvegica were not significantly affected by the treatment (Mann-Whitney $U$-test; $\mathrm{p}=0.903)$, but the $\delta^{13} \mathrm{C}$ values were significantly lower in fixed samples than in frozen ones $(\mathrm{p}=$ 0.037 ). The effect of the preservative treatment was not
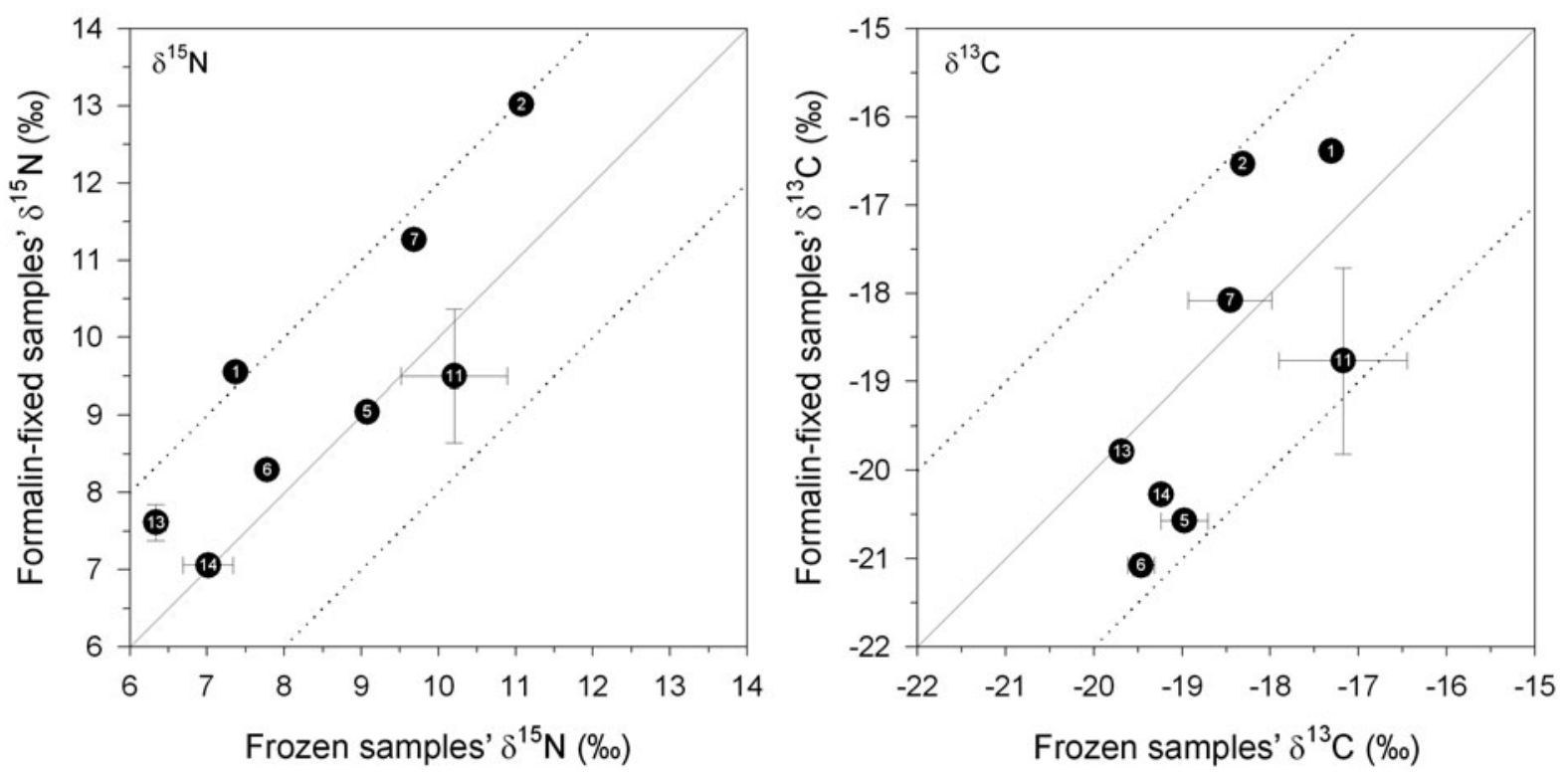

Fig. 2. Effect of preservative treatment (fixation with $4 \%$ formalin followed by preservation in $70 \%$ ethanol) on the mean $\delta^{13} \mathrm{C}$ and $\delta^{15} \mathrm{~N}$ values of 8 consumers sampled on the Santa Maria di Leuca coral mounds. SD (error bars) are shown when $\mathrm{n}>2$. 1:1 lines represent no effect; dotted lines indicate a $\pm 2 \%$ difference between fixed and frozen samples. Species codes (given in each black dot) are presented in Table 2 


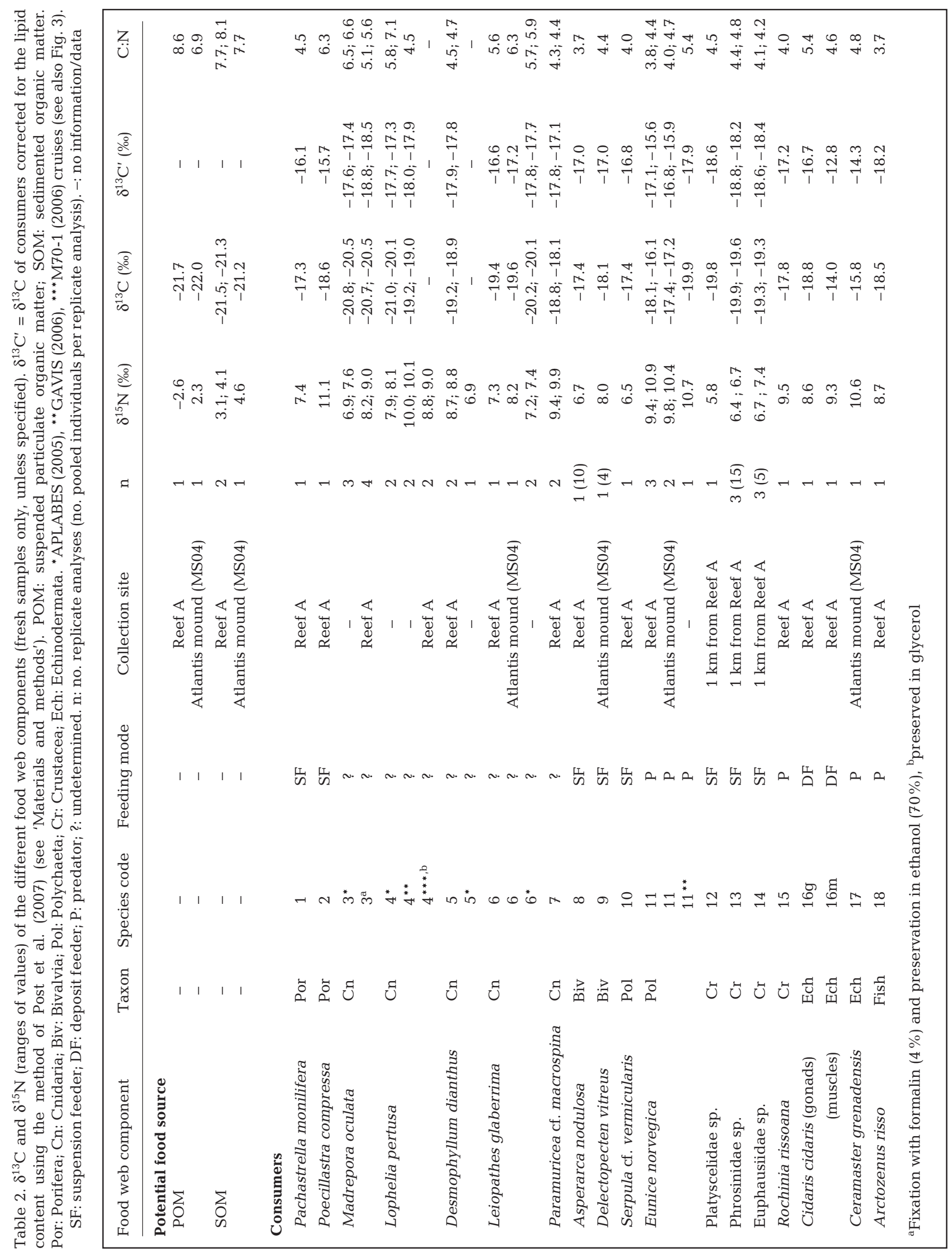


statistically tested with the 7 other species because of the insufficient number of samples. The mean $\delta^{15} \mathrm{~N}$ values of the cnidarians Desmophyllum dianthus and Leiopathes glaberrima were only slightly modified $\left(<0.5 \%\right.$ o) by the preservative treatment, but the $\delta^{15} \mathrm{~N}$ values of the gorgonian Paramuricea cf. macrospina were $1.5 \%$ higher in fixed samples than in frozen ones (Fig. 2).

Mean $\delta^{13} \mathrm{C}$ values of suspended POM and SOM from both sites were very similar, but SOM was much more ${ }^{15} \mathrm{~N}$-enriched (by $\sim 4 \%$ ) than POM (Table 2, Fig. 3A). There was a large difference in the $\delta^{15} \mathrm{~N}$ values of POM between the Reef A and Atlantis mound sampling sites. Mean $\delta^{13} \mathrm{C}$ and $\delta^{15} \mathrm{~N}$ values of consumers ranged from -21.0 to $-14.0 \%$ and 5.8 to $11.1 \%$, respectively (Table 2 , Fig. 3A). Mean $\delta^{13} \mathrm{C}^{\prime}$ values (corresponding to lipid-corrected $\delta^{13} \mathrm{C}$ values) of consumers collected in 2007 ranged from -18.8 to $-12.8 \%$ (Table 2, Fig. 3B). C:N values of POM and SOM were similar (6.9 to 8.6), whereas those of consumers ranged from 3.7 (Asperarca nodulosa and Arctozenus risso) to 7.1 (L. glaberrima) (Table 2).

Considering the primary consumers, pelagic grazers (amphipods and euphausiids) were significantly more ${ }^{13} \mathrm{C}$-depleted than benthic filter feeders (Mann-Whitney $U$-test, $\mathrm{p}=0.037$ ) (Fig. 3A,B). Conversely, $\delta^{15} \mathrm{~N}$ values were not significantly different between these 2 feeding guilds $(\mathrm{p}=0.134)$. The lack of significant difference was still relevant when the sponge Poecillastra compressa, which was particularly ${ }^{15} \mathrm{~N}$-enriched, was excluded from the analysis ( $\mathrm{p}=0.212$ ).

$\delta^{13} \mathrm{C}$ values of the 5 CWC species (Madrepora oculata, Lophelia pertusa, Desmophyllum dianthus, Leiopathes glaberrima and Paramuricea cf. macrospina) ranged from -21.0 to $-18.1 \%$, and their lipid-corrected $\delta^{13} \mathrm{C}^{\prime}$ values varied between -18.8 and $-16.6 \%$ (Table 2 ). $\delta^{15} \mathrm{~N}$ values of the same $5 \mathrm{CWC}$ species ranged from 6.9 to 10.1\% (Table 2). Among the CWC samples collected in 2007, the 2 scleractinians D. dianthus and M. oculata
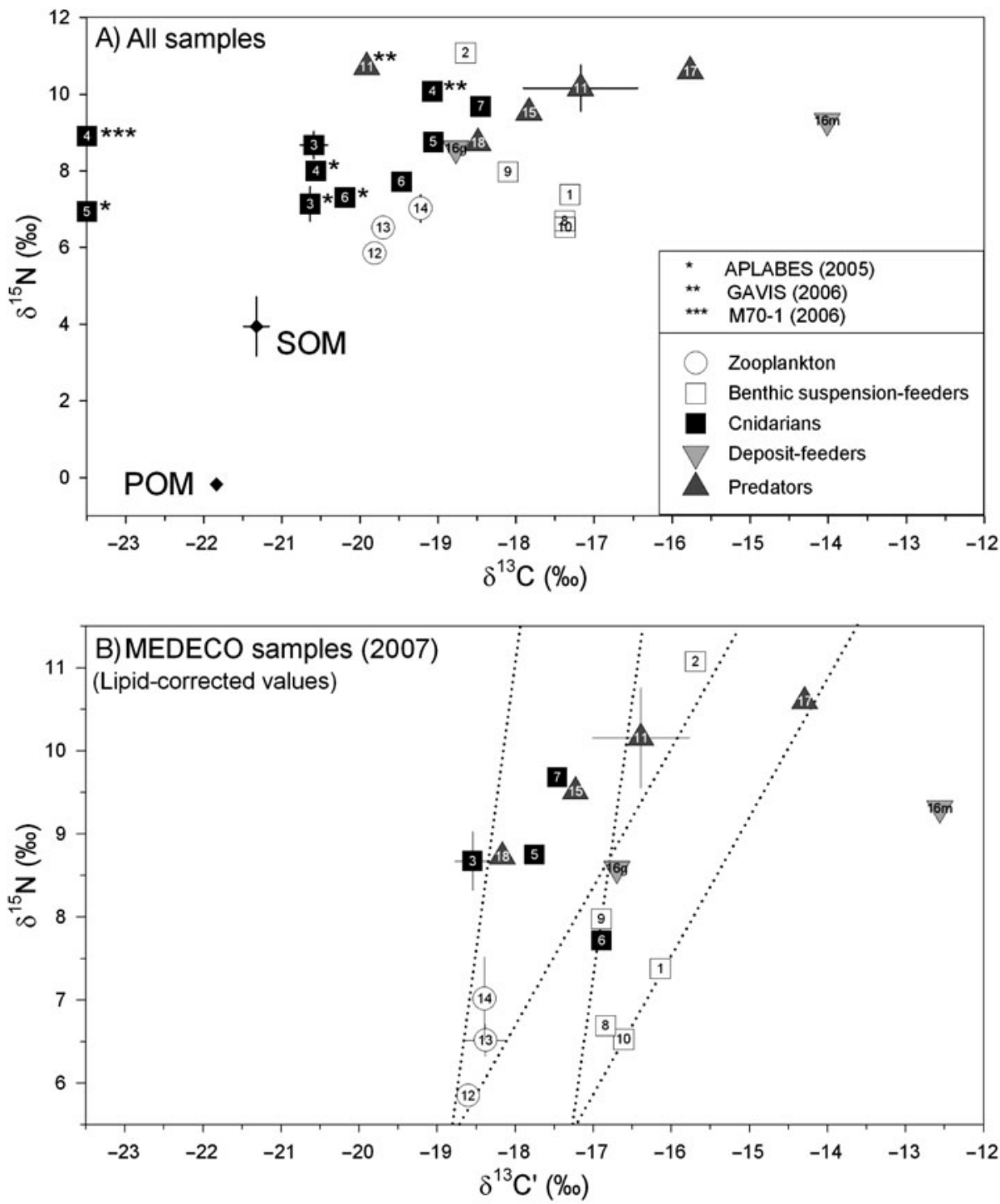

Fig. 3. (A) $\delta^{13} \mathrm{C}$ versus $\delta^{15} \mathrm{~N}$ biplot showing stable isotope composition of suspended particulate organic matter (POM), sedimented organic matter (SOM) and all samples of consumers collected on the Santa Maria di Leuca province. (B) Same as $\mathrm{A}$, but using lipid-corrected $\delta^{13} \mathrm{C}$ values $\left(\delta^{13} \mathrm{C}^{\prime}\right)$ and focusing on consumers collected during the MEDECO cruise (2007). Dotted lines represent theoretical trophic pathways based on consumption of either zooplankton or water-sediment interface filter feeders, and taking into account: (1) the ranges of published diet-consumer trophic enrichments (from +0.5 to $+1.5 \%$ for $\delta^{13} \mathrm{C}$ and from +2.5 to $+3.4 \%$ for $\delta^{15} \mathrm{~N}$ ) and (2) the isotopic variability found for each group of primary consumers. Species codes (given in each symbol) are presented in Table 2 
showed similar mean $\delta^{15} \mathrm{~N}$ values (8 to $9 \%$ ), whereas the gorgonian $P$. cf. macrospina and the antipatharian $L$. glaberrima were more ${ }^{15} \mathrm{~N}$-enriched (by $1 \%$ ) and ${ }^{15} \mathrm{~N}$ depleted (by $\sim 1 \%$ ), respectively.

\section{DISCUSSION}

\section{General food web structure}

POM collected $3 \mathrm{~m}$ above the bottom on SML coral mounds exhibited $\mathrm{C}: \mathrm{N}$ values ( 7 to 9$)$ similar to data reported for surface POM in the southern Adriatic and northern Ionian Seas (Socal et al. 1999, Boldrin et al. 2002) and match C:N ratios of living phytoplankton. $\delta^{13} \mathrm{C}$ values of POM ( - 22\%) also reflect the typical signature of marine phytoplanktonic production of this Mediterranean area (Martinotti et al. 1997, Sarà 2006). C:N values of SOM ( 8) were similar to those reported for sediment trap and sediment core sampling at nearby deep sites (870 to $1050 \mathrm{~m}$ depth) in the Otranto Strait (6.8, Boldrin et al. 2002; 6.8, Giordani et al. 2002). Despite a low number of replicates, C:N and $\delta^{13} \mathrm{C}$ values of SOM both suggest that POM of surface sediment originates mainly from relatively fresh phytoplankton detritus. The present study provides a first outlook of the isotopic composition of deep POM in the vicinity of SML CWC, but there is clearly a crucial need to better characterise the quality and availability of this potential food source. In particular, given the high turnover rate of phytoplankton with respect to animal tissues and the strong seasonal variability of particle supply to CWC (Mienis et al. 2009), the isotopic signal of POM and its temporal dynamics have to be better assessed in our study area.

$\delta^{13} \mathrm{C}$ values obtained for primary consumers $(-19.9<$ $\delta^{13} \mathrm{C}<-17.3 \%$; $-18.8<\delta^{13} \mathrm{C}^{\prime}<-15.7 \%$ ) indicate a benthic food web typically fuelled by phytoplanktonic production (Lepoint et al. 2000, Carlier et al. 2007). Consumers of higher trophic levels showed a similar range of $\delta^{13} \mathrm{C}$, albeit slightly higher and more variable due to a small trophic ${ }^{13} \mathrm{C}$-enrichment. The $\delta^{13} \mathrm{C}$ values obtained for the 5 cnidarian species (including the scleractinians Madrepora oculata and Lophelia pertusa) $\left(-21.0<\delta^{13} \mathrm{C}<-18.1 \%\right)$ fit well with $\delta^{13} \mathrm{C}$ data obtained for North Atlantic CWC (from -22.2 to $-19.3 \%$, Duineveld et al. 2004, 2007, Sherwood et al. 2008) and the Strait of Sicily, south of Malta (from -18.9 to $-18.2 \%$, CNR cruise CORAL of the RV 'Urania', 450$600 \mathrm{~m}$ ). Data obtained for the antipatharian Leiopathes glaberrima corroborate with those obtained for specimens from the Pacific (Roark et al. 2009). Our $\delta^{13} \mathrm{C}$ data highlight that the SML benthic food web is likely exclusively fuelled by carbon that ultimately originates from phytoplankton (either sedimenting from the euphotic layer and/or advected from the margin slope). This is in agreement with the existence of significant bottom currents in the southern Adriatic Sea (Boldrin et al. 2002) that likely enhance the seabed food supply. In the SML province, these currents are evidenced by (1) sediment drifts and erosional topographies (Taviani et al. 2005, Savini \& Corselli 2010), (2) coral distribution on the eastern flank of both mounds (Vertino et al. 2010, E. Le Guilloux unpubl. data) as well as their fan shape orientation and (3) distribution of human wastes that are mostly embedded in the coral colonies of the eastern mound's flanks. In addition, our $\delta^{13} \mathrm{C}$ data support the hypothesis that CWC communities do not rely on methanotrophically derived carbon for their food (Duineveld et al. 2004, 2007, Becker et al. 2009, Le Guilloux et al. 2009), which is much more ${ }^{13} \mathrm{C}$ depleted $(<40 \%$, Milkov 2005) than marine phytoplankton. Our results reinforced the view of Taviani et al. (2005) and Etiope et al. (2010) that no methane seepage occurs in the SML province.

However, the isotopic patterns obtained in the present study for all consumers (considering either $\delta^{13} \mathrm{C}$ or $\delta^{13} C^{\prime}$ values) suggest that the phytoplanktonic carbon source may not be assimilated via a single trophic pathway. Indeed, primary consumers that live and feed very close to the water-sediment interface (i.e. the polychaete Serpula vermicularis and the bivalve Asperarca nodulosa which were both collected at the dead base of the CWC framework, as well as the sponge Pachastrella monilifera collected on the seafloor) were clearly more ${ }^{13} \mathrm{C}$-enriched than pelagic grazers that surrounded the coral colonies (Fig. 3). Although the bivalves Delectopecten vitreus (living as epibionts on the trunk of a Leiopathes glaberrima bush) were located above the water-sediment interface, they were also more ${ }^{13} \mathrm{C}$-enriched than zooplankton. This could be linked to the fact that they were located in the muddy down-current side of the Atlantis mound where resuspended organic matter is available (see the discussion on the $\delta^{13} C^{\prime}$ values of L. glaberrima below).

A consistent trend was observed for consumers belonging to higher trophic levels. Cnidarians (whose polyps are located 30 to $40 \mathrm{~cm}$ above the seafloor) and consumers collected on the living, erected part of the CWC (e.g. the commensal eunicid Eunice norvegica and the spider crab Rochinia rissoana) showed low $\delta^{13} \mathrm{C}$ values that were similar to those of the mesopelagic fish Arctozenus risso which is mainly zooplanktivorous (Il'inskiy et al. 1995, Sherwood \& Rose 2005). Conversely, the 2 echinoderms Cidaris cidaris and Ceramaster grenadensis living and feeding most of the time on the bottom were more ${ }^{13} \mathrm{C}$-enriched. Incidentally, this is the first record of the seastar $C$. grenadensis on the SML coral bank and its isotopic signatures suggest this species occupies the third trophic 
level (secondary consumers) and ultimately depends on a ${ }^{13} \mathrm{C}$-enriched source of organic matter (Fig. 3). Therefore, the obtained $\delta^{13} \mathrm{C}$ pattern suggests that the phytoplanktonic source can be incorporated into the benthic food web by 2 trophic pathways: a slightly ${ }^{13} \mathrm{C}$-depleted pathway originating from relatively fresh/labile organic matter, and a slightly ${ }^{13} \mathrm{C}$-enriched pathway deriving from more decayed organic matter. Such a discrepancy has already been described for offshore benthic ecosystems (Hobson et al. 1995, Iken et al. 2001, Nadon \& Himmelman 2006), but it is still unclear why sedimented and reworked organic matter would be more ${ }^{13} \mathrm{C}$-enriched than freshly sedimented organic matter (Nadon \& Himmelman 2006). On the SML coral province, the assimilation of ${ }^{13} \mathrm{C}$-enriched food sources like detritus of macroalgae or microphytobenthos can be excluded at these depths. Rather, the ${ }^{13} \mathrm{C}$-enrichment may be linked to the assimilation of a more degraded phytoplanktonic production (Kharlamenko et al. 2008) and/or degraded secondary benthic production. It would be interesting to investigate the role of coral mucus as a possible candidate in this ${ }^{13} \mathrm{C}$ enrichment, since mucus is produced in abundance by tropical reef corals and has been shown to supply significant amounts of energy and nutrients to the sediment (Wild et al. 2004).

The isotopic pattern described above is only weakly modified when $\delta^{13} \mathrm{C}$ values are normalised for the tissue lipid content which is inferred from the C:N ratios. The only noticeable change concerns the antipatharian Leiopathes glaberrima, which exhibited a high C:N ratio and became more ${ }^{13} \mathrm{C}$-enriched than other cnidarians after lipid-correction. This shift towards higher $\delta^{13} \mathrm{C}$ could be explained by a mixed diet composed of fresh (POM and, to a lesser extent, small zooplankton, see below) and more degraded (resuspended) organic matter. The assimilation of degraded and resuspended organic matter by L. glaberrima could be linked to its location on the down-current side of the mounds where resuspended material may redeposit and be captured by bush-like cnidarians. This hypothesis is supported by the fact that, on Atlantis mound, L. glaberrima exhibits a distinct spatial distribution with respect to the framework-building scleractinians Madrepora oculata, Lophelia pertusa and Desmophyllum dianthus, which occupy the up-current side of the mound (Vertino et al. 2010). In this sense, our results corroborate those of Sherwood et al. (2008), who argued that coral species living on current-swept hard substrata are more ${ }^{13} \mathrm{C}$-depleted than coral species inhabiting areas where resuspended material is more available. Our results confirm previous hypotheses of the influence of near-bottom currents and water turbulence on faunal distribution patterns (Mortensen et al. 1995) and their important role in the trophic ecology of CWC (Sherwood et al. 2008).

\section{Diet of CWC species in SML banks}

POM is certainly a key component of the trophic ecology of CWC. The high $\delta^{15} \mathrm{~N}$ variability we obtained for POM collected $3 \mathrm{~m}$ above the bottom may be linked to: (1) strong spatial heterogeneity in the POM quality due to the complex hydrodynamic (i.e. variable contribution of resuspended material to the POM pool) and/or (2) insufficient nitrogen collected on the filters with respect to the analytical limit of the mass spectrometer. Low nitrogen content at 500 to $700 \mathrm{~m}$ depth can be explained by the fact that particulate organic nitrogen rapidly decreases with depth as POM is decayed during sinking to the sea floor, especially in the warm $\left(\sim 14^{\circ} \mathrm{C}\right)$, deep Mediterranean Sea. Thus, we cannot exclude the possibility that the volumes of filtered water were insufficient. In light of the $\delta^{15} \mathrm{~N}$ values (2 to $7 \%$ ) previously reported for POM on Rockall Trough CWC (Duineveld et al. 2007, Mienis et al. 2009), we only consider in the present study the value obtained on Atlantis mound (2.3\%).

Nevertheless, even when considering the highest $\delta^{15} \mathrm{~N}$ value of POM $(2.3 \%)$, the scleractinian corals Madrepora oculata and Desmophyllum dianthus and the gorgonian Paramuricea cf. macrospina sampled in 2007 together with POM were ${ }^{15} \mathrm{~N}$-enriched by 6 to $10 \%$ relative to this potential food source. This difference is well above the classical ${ }^{15} \mathrm{~N}$ consumer-diet enrichment of 2.5 to $3.4 \%$ (Vander Zanden \& Rasmussen 2001, Vanderklift \& Ponsard 2003). Thus, these corals likely do not assimilate POM directly. Conversely, the $\delta^{15} \mathrm{~N}$ values of these 3 cnidarians were 1 to $4 \%$ higher than those of zooplankton collected alive around coral patches. In addition, they were similar to, or even slightly higher than, the $\delta^{15} \mathrm{~N}$ values of the zooplanktivorous fish Arctozenus risso. The results obtained for M. oculata, D. dianthus and P. cf. macrospina are then consistent with a diet mainly based on zooplankton (mainly phrosinid and platyscelid amphipods). This hypothesis agrees with previous conclusions drawn based on the lipid markers and $\delta^{15} \mathrm{~N}$ data (6.8 to $8.6 \%$ ) of $M$. oculata from the NE Atlantic (Kiriakoulakis et al. 2005). Our outcomes differ, however, from a previous study of the Galicia Bank coral reef, where small crustaceans (copepods) were slightly more ${ }^{15} \mathrm{~N}$-enriched than Lophelia pertusa and $\mathrm{M}$. oculata and were, thus, probably not a major food source for these CWC (Duineveld et al. 2004). Although $L$. pertusa from SML seems to mainly feed on zooplankton (as suggested by its high $\delta^{15} \mathrm{~N}$ values), it remains difficult to draw conclusions about its diet composition since this species was sampled in 2005 and 2006 and we did not sample any of its potential food sources for these periods. The mean $\delta^{15} \mathrm{~N}$ obtained for $L$. pertusa and $M$. oculata in the present study are in the ranges of 
values already reported for these 2 species in the NE Atlantic (8.7 to 9.3 and 6.8 to $9.5 \%$, respectively, Duineveld et al. 2004, 2007, Kiriakoulakis et al. 2005) and in the Strait of Sicily, south of Malta (9.2 and 8.0\%o, respectively, CNR cruise CORAL of the RV 'Urania', 450-600 m). However, data obtained for fixed samples (either with formalin or with glycerol) must be considered with caution since they could have been modified by the preservative treatment. There is no consensus about the effect of formalin on $\delta^{15} \mathrm{~N}$ values of aquatic species. Some authors found no significant effect (Sarakinos et al. 2002), whereas other studies evidenced significant $\delta^{15} \mathrm{~N}$ shifts (Bosley \& Wainright 1999, Edwards et al. 2002). Given the positive $\delta^{15} \mathrm{~N}$ shift we obtained between fresh and fixed samples of 3 cnidarian species (Fig. 2), we cannot exclude the possibility that $\delta^{15} \mathrm{~N}$ of $M$. oculata sampled in 2007 has been overestimated. Indeed, fresh samples of $M$. oculata collected at the same depth in 2005 were slightly more ${ }^{15} \mathrm{~N}$-depleted, by $1 \%$. Therefore additional $\delta^{15} \mathrm{~N}$ analyses on fresh material are clearly required to confirm the diet of these 2 cosmopolitan coral species in the SML CWC province.

Isotopic data obtained for the gorgonian Paramuricea cf. macrospina are in agreement with stomach content analysis of the aposymbiontic P. clavata in a shallow (30 m depth) NW Mediterranean area (Coma et al. 1994). Indeed, according to these authors small zooplankton (100 to $200 \mu \mathrm{m}$ ) plays a major role ( $78 \%$ of the captured prey items) in the diet of this gorgonian. Given the small polyp size of $P$. cf. macrospina, this gorgonian probably does not feed on the euphausiids and platyscelid amphipods but rather on phrosinid amphipods. This hypothesis is supported by the $\delta^{15} \mathrm{~N}$ differences between the gorgonian and the phrosinids from SML (2.7 to $3.5 \%$ ) corresponding to the classical trophic ${ }^{15} \mathrm{~N}$-enrichment. Nevertheless, in the light of the work by Coma et al. (1994), it would be also relevant to consider smaller zooplankton $(<250 \mu \mathrm{m})$ of SML, in particular copepods that are abundant in this area (Mastrototaro et al. 2010), in order to assess their potentially important trophic role.

The antipatharian Leiopathes glaberrima is able to prey on small zooplankton (such as phrosinids) as observed in several polyps of the specimens collected during the MEDECO cruise. However, its $\delta^{15} \mathrm{~N}$ values, which reflect diet over the time corresponding to the turnover of the tissue, were lower than those of gorgonian and scleractinians, suggesting that zooplankton play a lower trophic role for L. glaberrima than for the 4 other CWC species. Moreover, on Atlantis mound, L. glaberrima exhibited the same $\delta^{15} \mathrm{~N}$ value as the suspension-feeding bivalve Delectopecten vitreus, suggesting a high contribution of POM in the diet of the black coral. Thus the high number of prey found on a single branch of the antipatharian could result from the fact that the ROV lights attracted a multitude of zooplankton, temporarily enhancing the probability of their capture by coral polyps.

Recent video recordings on the SML banks revealed that amphipods and euphausiids are abundant around the coral colonies (Mastrototaro et al. 2010). However, we still do not know if this represents a permanent food source for the CWC in this Mediterranean area. Zooplankton are prone to nocturnal upwards migration and current-induced horizontal transfer in surface water (Macquart-Moulin 1993) and show variation in seasonal abundance in the CWC community of the Galicia Bank (Duineveld et al. 2004). Therefore, euphausiids, amphipods and copepods could only be available seasonally for benthic consumers in the SML. This question should be resolved through repeated seasonal sampling in the area.

The major contribution of zooplankton to the diet of scleractinian corals and the ${ }^{13} \mathrm{C}$-enrichment of benthic consumers feeding at the water-sediment interface with respect to those feeding well above the bottom have to be confirmed by a more extensive sampling effort. Nevertheless, our results suggest that the location in the coral framework and the consequent relative exposure to surface sediment and resuspension processes may influence the feeding habits of CWC and related benthic consumers in the SML province.

Acknowledgements. We thank the captain and the crew of the RV 'Pourquoi pas?' as well as the team of the ROV 'Victor 6000 '. The MEDECO cruise (2007) (chief scientist: J. Sarrazin) was funded by Ifremer and the HERMES European program. Thanks are due to the captain, crew and colleagues onboard RV 'Urania' during cruise CORSARO (2007). Thanks are also due to A. Vertino and J. Grall for their help in the identification of fauna. Stable isotope analyses were performed by Mylnefield Research Services. We also thank P. Richard for his help in stable isotope analysis. We are grateful to C. Le Gall for in situ POM sampling and B. Loubrieu for processing the multibeam echo-sounder data. A.C. was funded by a postdoctoral fellowship from HERMES and the ANR DeepOases; E.L.G. was funded by HERMES, Ifremer and Region Bretagne. This paper is a contribution to the EU Hermione programme (contract number 226354) and is ISMAR-Bologna scientific contribution no. 1672.

\section{LITERATURE CITED}

Anthony KRN, Fabricius KE (2000) Shifting roles of heterotrophy and autotrophy in coral energetics under varying turbidity. J Exp Mar Biol Ecol 252:221-253

> Becker EL, Cordes EE, Macko SA, Fisher CR (2009) Importance of seep primary production to Lophelia pertusa and associated fauna in the Gulf of Mexico. Deep-Sea Res I 56:786-800

Bethoux JP, Gentili B, Raunet J, Tailliez D (1990) Warming trend in the western Mediterranean deep water. Nature 347:660-662 
Beuck L, Freiwald A, Taviani M (2010) Spatiotemporal bioerosion patterns in deep-water scleractinians from off Santa Maria di Leuca (Apulia, Ionian Sea). Deep-Sea Res II (in press), doi:10.1016/j.dsr2.2009.08.019

Boldrin A, Miserocchi S, Rabitti S, Turchetto MM, Balboni V, Socal G (2002) Particulate matter in the southern Adriatic and Ionian Sea: characterisation and downward fluxes. J Mar Syst 33-34:389-410

Bosley KL, Wainright SC (1999) Effects of preservatives and acidification on the stable isotope ratios $\left({ }^{15} \mathrm{~N}:{ }^{14} \mathrm{~N},{ }^{13} \mathrm{C}:{ }^{12} \mathrm{C}\right)$ of two species of marine animals. Can J Fish Aquat Sci 56:2181-2185

Budillon G, Bue NL, Siena G, Spezie G (2010) Hydrographic characteristics of water masses and circulation in the Northern Ionian Sea. Deep-Sea Res II (in press) doi:10.1016/j.dsr2.2009.08.022

Carlier A, Riera P, Amouroux JM, Bodiou JY, Grémare A (2007) Benthic trophic network in the Bay of Banyuls-surMer (northwest Mediterranean, France): an assessment based on stable carbon and nitrogen isotopes analysis. Estuar Coast Shelf Sci 72:1-15

Coma R, Gili JM, Zabala M, Riera T (1994) Feeding and prey capture cycles in the aposymbiontic gorgonian Paramuricea clavata. Mar Ecol Prog Ser 115:257-270

Corselli C, Favali P, Rosso MA, Spezie G and others (2006) The 'Santa Maria di Leuca' Lophelia reefs of the Mediterranan Sea: state-of-the-art and on-going research. Geophys Res Abstr 8:05714

Costello M, McCrea M, Freiwald A, Lundälv T and others (2005) Role of cold-water Lophelia pertusa coral reefs as fish habitat in the NE Atlantic. In: Friewald A, Roberts JM (eds) Cold-water corals and ecosystems. Springer, Berlin, p 771-805

D'Onghia G, Maiorano P, Sion L, Giove A, Capezzuto F, Carlucci R, Tursi A (2010) Effects of deep-water coral banks on the abundance and size structure of the megafauna in the mediterranean sea. Deep-Sea Res II (in press) doi:10.1016/j.dsr2.2009.08.22

$>$ DeNiro MJ, Epstein S (1977) Mechanism of carbon isotope fractionation associated with lipid synthesis. Science 197: 261-263

Duineveld GCA, Lavaleye MSS, Berghuis EM (2004) Particle flux and food supply to a seamount cold-water coral community (Galicia Bank, NW Spain). Mar Ecol Prog Ser 277:13-23

Duineveld GCA, Lavaleye MSS, Bergman MJN, de Stigter H, Mienis F (2007) Trophic structure of a cold-water coral mound community (Rockall Bank, NE Atlantic) in relation to the near-bottom particle supply and current regime. Bull Mar Sci 81:449-467

Edwards MS, Turner TF, Sharp ZD (2002) Short- and longterm effects of fixation and preservation on stable isotope values $\left(\delta^{13} \mathrm{C}, \delta^{15} \mathrm{~N}, \delta^{34} \mathrm{~S}\right)$ of fluid-preserved museum specimens. Copeia 4:1106-1112

Etiope G, Savini A, Lo Bue N, Favali P, Corselli C (2010) Deep-sea survey for the detection of methane at the 'Santa Maria di Leuca' cold-water coral mounds (Ionian Sea, South Italy). Deep-Sea Res II (in press) doi:10.1016/ j.dsr2.2009.08.020

Fosså JH, Mortensen PB, Furevik DM (2002) The deep-water coral Lophelia pertusa in Norwegian waters: distribution and fishery impacts. Hydrobiologia 471:1-12

Freiwald A (2002) Reef-forming cold-water corals. In: Wefer G, Billett D, Hebbeln D, Jørgensen BB, Schlüter M, van Weering TCE (eds) Ocean margin systems. Springer, Heidelberg, p 365-385

Freiwald A, Fosså JH, Grehan A, Koslow T, Roberts JM (2004) Cold-water coral reefs. UNEP-WCMC, Cambridge
Freiwald A, Beuck L, Rüggeberg A, Taviani M, Hebbeln D, Participants RVMCM (2009) The white coral community in the Central Mediterranean Sea revealed by ROV surveys. Oceanography 22:58-74

Fry B (2006) Stable isotope ecology. Springer, New York

Giordani P, Helder W, Koning E, Miserocchi S, Danovaro R, Malaguti A (2002) Gradients of benthic-pelagic coupling and carbon budgets in the Adriatic and Northern Ionian Sea. J Mar Syst 33-34:365-387

Hamoutene D, Puestow T, Miller-Banoub J, Wareham V (2008) Main lipid classes in some species of deep-sea corals in the Newfoundland and Labrador region (Northwest Atlantic Ocean). Coral Reefs 27:237-246

> Henry LA, Roberts JM (2007) Biodiversity and ecological composition of macrobenthos on cold-water coral mounds and adjacent off-mound habitat in the bathyal Porcupine Seabight, NE Atlantic. Deep-Sea Res I 54:654-672

> Hobson KA, Ambrose WG Jr, Renaud PE (1995) Sources of primary production, benthic-pelagic coupling, and trophic relationships within the Northeast Water Polynya: insights from $\delta^{13} \mathrm{C}$ and $\delta^{15} \mathrm{~N}$ analysis. Mar Ecol Prog Ser 128:1-10

Houlbrèque F, Ferrier-Pagès C (2009) Heterotrophy in tropical scleractinian corals. Biol Rev Camb Philos Soc 84:1-17

Husebø Å, Nøttestad L, Fosså JH, Furevik DM, Jørgensen SB (2002) Distribution and abundance of fish in deep-sea coral habitats. Hydrobiologia 471:91-99

> Iken K, Brey T, Wand U, Voigt J, Junghans P (2001) Food web structure of the benthic community at the Porcupine Abyssal Plain (NE Atlantic): a stable isotope analysis. Prog Oceanogr 50:383-405

Il'inskiy EN, Balanov AA, Ivanov OA (1995) Rare mesopelagic fishes Scopelosaurus harryi, Arctozenus rissoi, Magnisudis atlantica and Tactostoma macropus from the Northwest Pacific. 2. Spatial distribution and biology. J Ichthyol 35: $1-19$

- Kharlamenko V, Kiyashko S, Rodkina S, Imbs A (2008) Determination of food sources of marine invertebrates from a subtidal sand community using analyses of fatty acids and stable isotopes. Russ J Mar Biol 34:101-109

Kiriakoulakis K, Fisher E, Wolff GA, Freiwald A, Grehan A, Roberts JM (2005) Lipids and nitrogen isotopes of two deep-water corals from the North-East Atlantic: initial results and implications for their nutrition. In: Friewald A, Roberts JM (eds) Cold-water corals and ecosystems. Springer, Berlin, p 715-729

Kiriakoulakis K, Freiwald A, Fisher E, Wolff G (2007) Organic matter quality and supply to deep-water coral/mound systems of the NW European Continental Margin. Int J Earth Sci 96:159-170

Krieger KJ, Wing BL (2002) Megafauna associations with deepwater corals (Primnoa spp.) in the Gulf of Alaska. Hydrobiologia 471:83-90

Le Guilloux E, Olu K, Bourillet JF, Savoye B, Iglésias SP, Sibuet M (2009) First observations of deep-sea coral reefs along the Angola margin. Deep-Sea Res II 56:2394-2403

> Lepoint G, Nyssen F, Gobert S, Dauby P, Bouquegnea JM (2000) Relative impact of a seagrass bed and its adjacent epilithic algal community in consumer diets. Mar Biol 136: 513-518

Macquart-Moulin C (1993) Repartition verticale, migrations et stratifications superficielles des Mysidaces et Amphipodes pelagiques sur les marges mediterraneenne et atlantique franchises. J Plankton Res 15:1149-1170

Martinotti W, Camusso M, Guzzi L, Patrolecco L, Pettine M (1997) C, N and their stable isotopes in suspended and sedimented matter from the Po estuary (Italy). Water Air Soil Pollut 99:325-332 
Mastrototaro F, Matarrese A, Tursi A (2002) Un mare di coralli in Mar Ionio. Biol Mar Mediterr 9:616-619

Mastrototaro F, D'Onghia G, Corriero G, Matarrese A and others (2010) Biodiversity of the white coral bank off Cape Santa Maria di Leuca (Mediterranean Sea): an update. Deep-Sea Res II (in press), doi:10.1016/j.dsr2.2009.08.021

$>$ McConnaughey T, McRoy CP (1979) Food-web structure and the fractionation of carbon isotopes in the Bering Sea. Mar Biol 53:257-262

Mienis F, de Stigter HC, de Haas H, van Weering TCE (2009) Near-bed particle deposition and resuspension in a coldwater coral mound area at the Southwest Rockall Trough margin, NE Atlantic. Deep-Sea Res I 56:1026-1038

Milkov AV (2005) Molecular and stable isotope compositions of natural gas hydrates: a revised global dataset and basic interpretations in the context of geological settings. Org Geochem 36:681-702

Mortensen PB (2001) Aquarium observations on the deepwater coral Lophelia pertusa (L., 1758) (Scleractinia) and selected associated invertebrates. Ophelia 54:83-104

Mortensen PB, Hovland M, Brattegard T, Farestveit R (1995) Deep water bioherms of the scleractinian coral Lophelia pertusa (L.) at $64^{\circ} \mathrm{N}$ on the Norwegian shelf: structure and associated megafauna. Sarsia 80:145-158

Nadon MO, Himmelman JH (2006) Stable isotopes in subtidal food webs: Have enriched carbon ratios in benthic consumers been misinterpreted? Limnol Oceanogr 51: 2828-2836

Orejas C, Lo Iacono C, Gori A, Gili JM, Puig P (2008) Detection and characterization of deep-coral banks in the Cap de Creus Canyon (North western Mediterranean) using visual and acoustic methods. Geophys Res Abstr 10: EGU2008-A-06712

Pérès JM (1967) The Mediterranean benthos. Oceanogr Mar Biol Annu Rev 5:449-533

Post DM, Layman CA, Arrington DA, Takimoto G, Quattrochi J, Montaña CG (2007) Getting to the fat of the matter: models, methods and assumptions for dealing with lipids in stable isotope analyses. Oecologia 152:179-189

Riera P, Richard P, Grémare A, Blanchard G (1996) Food source of intertidal nematodes in the Bay of MarennesOléron (France), as determined by dual stable isotope analysis. Mar Ecol Prog Ser 142:303-309

Roark EB, Guilderson TP, Dunbar RB, Fallon SJ, Mucciarone DA (2009) Extreme longevity in proteinaceous deep-sea corals. Proc Natl Acad Sci USA 106:5204-5208

Roberts JM, Wheeler AJ, Freiwald A (2006) Reefs of the deep: the biology and geology of cold-water coral ecosystems. Science 312:543-547

Ross SW, Quattrini AM (2007) The fish fauna associated with deep coral banks off the southeastern United States. Deep-Sea Res I 54:975-1007

Sarà G (2006) Hydrodynamic effects on the origin and quality of organic matter for bivalves: an integrated isotopic, biochemical and transplant study. Mar Ecol Prog Ser 328: $65-73$

Submitted: March 2, 2009; Accepted: October 7, 2009
Sarakinos HC, Johnson ML, Zanden MJV (2002) A synthesis of tissue-preservation effects on carbon and nitrogen stable isotope signatures. Can J Zool 80:381-387

Savini A, Corselli C (2010) High-resolution bathymetry and acoustic geophysical data from Santa Maria di Leuca cold water coral province (Northern Ionian sea - Apulian continental slope). Deep-Sea Res II (in press), doi:10.1016/ j.dsr2.2009.08.014

Schembri P, Dimech M, Camilleri M, Page R (2007) Living deep-water Lophelia and Madrepora corals in Maltese waters (Strait of Sicily, Mediterranean Sea). Cah Biol Mar 48:77-83

> Sherwood GD, Rose GA (2005) Stable isotope analysis of some representative fish and invertebrates of the Newfoundland and Labrador continental shelf food web. Estuar Coast Shelf Sci 63:537-549

Sherwood OA, Jamieson RE, Edinger EN, Wareham VE (2008) Stable C and N isotopic composition of cold-water corals from the Newfoundland and Labrador continental slope: examination of trophic, depth and spatial effects. Deep-Sea Res I 55:1392-1402

Socal G, Boldrin A, Bianchi F, Civitarese G and others (1999) Nutrient, particulate matter and phytoplankton variability in the photic layer of the Otranto strait. J Mar Syst 20: 381-398

Taviani M, Remia A, Corselli C, Freiwald A and others (2005) First geo-marine survey of living cold-water Lophelia reefs in the Ionian Sea (Mediterranean basin). Facies 50: 409-417

Thiem Ø, Ravagnan E, Fosså JH, Berntsen J (2006) Food supply mechanisms for cold-water corals along a continental shelf edge. J Mar Syst 60:207-219

Turley C, Roberts J, Guinotte J (2007) Corals in deep-water: Will the unseen hand of ocean acidification destroy coldwater ecosystems? Coral Reefs 26:445-448

Tursi A, Mastrototaro F, Matarrese A, Maiorano P, Donghia G (2004) Biodiversity of the white coral reefs in the Ionian Sea (Central Mediterranean). Chem Ecol 20:107-116

Vander Zanden MJ, Rasmussen JB (2001) Variation in $\delta^{15} \mathrm{~N}$ and $\delta^{13} \mathrm{C}$ trophic fractionation: implications for aquatic food web studies. Limnol Oceanogr 46:2061-2066

Vanderklift MA, Ponsard S (2003) Sources of variation in consumer-diet $\delta^{15} \mathrm{~N}$ enrichment: a meta-analysis. Oecologia 136:169-182

Vertino A, Savini A, Rosso A, Di Geronimo I and others (2010) Benthic habitat characterization and distribution from two representative sites of the deep-water SML coral mound province (Mediterranean). Deep-Sea Res II (in press), doi:10.1016/j.dsr2.2009.08.023

Wild C, Huettel M, Klueter A, Kremb SG, Rasheed MYM, Jorgensen BB (2004) Coral mucus functions as an energy carrier and particle trap in the reef ecosystem. Nature 428:66-70

Zibrowius H (1980) Les scléractiniaires de la Méditerranée et de l'Atlantique nord-oriental. Mem Inst Oceanogr (Monaco) 11:117

Proofs received from author(s): December 4, 2009 